\title{
KOMUNIKASI TERAPEUTIK KONSELOR ADIKSI PADA KORBAN PENYALAHGUNAAN NARKOBA DI RUMAH PALMA THERAPEUTIC COMMUNITY KABUPATEN BANDUNG BARAT
}

\author{
Rachmawati Windyaningrum \\ Program Studi Ilmu Komunikasi, Universitas Komputer Indonesia (UNIKOM)
}

\begin{abstract}
ABSTRAK
Program rehabilitasi pecandu narkoba yang dilakukan secara komunitas, didasarkan atas penggunaan komunikasi dalam komunitas sebagai metode terapi dan rehabilitasi. Program rehabilitasi narkoba yang dimiliki pemerintah Jawa Barat dengan berbasis rumah sakit menggunakan pelayanan metode rehabilitasi therapeutic community. Rumah Palma Therapeutic Community dijadikan sebagai pusat rujukan terapi dan rehabilitasi adiksi dalam membina pecandu narkoba bertujuan membangun kesadaran dalam diri pecandu agar membentuk perilaku yang bernilai dan sesuai dengan pemulihan. Tujuan penelitian ini adalah menemukan metode terapi komunikasi konselor adiksi dalam membantu pemulihan residen, dukungan keluarga pada komunikasi terapeutik konselor adiksi, dan alasan mantan pecandu yang menjadi konselor adiksi. Penelitian ini menggunakan metode kualitatif dengan pendekatan studi kasus eksplanatoris. Informan penelitian adalah konselor adiksi yang dipilih secara purposive sampling. Data diperoleh melalui wawancara mendalam, observasi partisipan, dan dokumentasi. Hasil penelitian menunjukkan metode terapi komunikasi yang dilakukan konselor adiksi adalah static counseling dan individual counseling. Metode terapi komunikasi tidak terlepas dari kedekatan, kenyamanan, kepercayaan diantara konselor dan residen. Penggunaan komunikasi diantara mereka ditunjukkan dengan bahasa verbal dan nonverbal. Dukungan keluarga residen ditunjukkan dengan adanya komitmen terhadap treatment pemulihan, keaktifan keluarga pada family support group dan family dialog. Alasan mantan pecandu menjadi konselor adiksi karena mereka dapat menjadi role model bagi residen dalam program pemulihan, adanya panggilan hati untuk membantu sesama pecandu, dan sebagai bentuk recovery maintainance setelah mereka selesai menjalani program pemulihan.
\end{abstract}

Kata-kata Kunci: Komunikasi terapeutik, konselor adiksi, korban penyalahgunaan narkoba, pemulihan

\section{THERAPEUTIC COMMUNICATION BY ADDICTION COUNSELORS ON VICTIMS OF DRUGS ABUSE AT RUMAH PALMA THERAPEUTIC COMMUNITY OF WEST BANDUNG REGENCY}

\section{ABSTRACT}

Drug addict rehabilitation program conducted, based on communication within the community as a method of therapy and rehabilitation. Drug rehabilitation program owned by government of West Java Province is using hospital based on therapeutic community rehabilitation methods. Rumah Palma Therapeutic Community becomes a refference in addiction treatment and drug adicts rehabilitation, with the objectives of building, the addicts awareness in shaping their behavior to reach a particular conduct values and inline with the goal of the recovery. The purpose of this research are: to find a method of communication therapy for addiction counselor in aiding the recovery of the resident, to investigate family support in therapeutic communication of addiction counselor, and the reason for exaddict to become a addiction counselor. This research uses qualitative method with explanatory case study approach. The informants are addiction counselors selected based on purposive sampling. Data were obtained through in-depth interviews, participant observation, and documentation. The results shows that the method of communication therapy of addiction counselor are static counseling and individual counseling. Therapeutic methods of communication can't be separated from the closeness, comfort, and trust between the counselor and resident. The use of communication between addiction counselor and drug addict is by verbal and nonverbal language. Result shows that Resident family supports show the commitment to the recovery treatment, the activity of a family in the family support group and family dialogue. The reasons for the former addict to become addiction counselor are because they can become role models for residents in the recovery program, voluntary call to help fellow addicts, and as a form of recovery maintenance after they completed a recovery program.

Keywords: Therapeutic communication, addiction counselors, victims of abuse drugs, recovery

Korespondensi: Rachmawati Windyaningrum, M.I.Kom. Program Studi Ilmu Komunikasi Universitas Komputer Indonesia (UNIKOM) Jl. Dipati Ukur No. 112-114 Bandung, 40132 Email: rachma_h2@yahoo.com 


\section{PENDAHULUAN}

Program rehabilitasi bagi para pecandu narkoba, didasarkan atas penggunaan komunikasi dalam komunitas sebagai metode terapi dan rehabilitasi. Penggunaan komunikasi yang tercipta diantara pecandu narkoba sebagai anggota komunitas dengan para konselor adiksi mengarah pada proses terapi. Metode terapi dan rehabilitasi melalui komunitas dikenal dengan istilah therapeutic community. Rumah Palma Therapeutic Community termasuk dalam bagian dari Unit Napza Rumah Sakit Jiwa Provinsi Jawa Barat merupakan panti rehabilitasi yang berbasis rumah sakit. Rumah Palma Therapeutic Community dijadikan sebagai pusat rujukan terapi dan rehabilitasi adiksi dalam membina pecandu narkoba dilakukan dengan pendekatan therapeutic community. Pendekatan ini bertujuan untuk membangun kesadaran dalam diri pecandu agar membentuk perilaku yang bernilai dan sesuai dengan pemulihan.

Metode terapi dan rehabilitasi dengan pendekatan therapeutic community tidak terlepas dari komunikasi terapeutik yang dilakukan konselor adiksi berfungsi untuk menciptakan suasana nyaman bagi para residen yang merupakan pecandu narkoba pada program rehabilitasi. Selain itu, komunikasi terapeutik yang dilakukan konselor adiksi dapat mengungkapkan apa yang residen rasakan, sehingga konselor adiksi dapat memberi solusi atas apa yang telah dirasakan residen. Para konselor adiksi Rumah Palma Therapeutic Community dalam membantu residen dimulai dengan menjalin hubungan kedekatan yang dilandasi oleh rasa empati. Rasa empati merupakan tahapawal konselor untuk membangun hubungan interaksi yang terapeutik. Konselor adiksi pun dapat mengetahui apa yang menjadi permasalahan atau isu dalam diri kliennya, sehingga selain mengurangi beban klien, konselor dapat mengetahui treatment apa yang sesuai berdasarkan kebutuhan klien sebagai residen. Tak hanya rasa empati, konselor adiksi Rumah Palma dituntut menciptakan suasana nyaman bagi residennya.

Suasana nyaman itu terlihat pada saat residen menggunakan istilah brother (kakak) untuk memanggil konselornya. Dengan posisi konselor sebagai brother, residen merasakan kenyamanan dan pada akhirnya dapat terbuka untuk menceritakan permasalahan yang dihadapinya. Hal ini dikarenakan, therapeutic community mengusung konsep kekeluargaan sehinggakonseloradiksidianggapsebagaibagian dari keluarga residen. Penerapan komunikasi terapeutik dalam membantu pemulihan residen, karena residen di Rumah Palma kerap mengalami masalah. Permasalahan yang kerap kali dialami oleh residen adalah sulitnya residenmenerima program pemulihan melalui therapeutic community. Hal ini dikarenakan, Therapeutic Community bersifat pembelajaran sosial dengan seperangkat aturan yang mengikat dan berbagai aktivitas yang terjadwal. Banyak residen masih mengganggap proses terapi dan rehabilitasi narkoba itu menyakitkan layaknya dalam jeruji besi. Rumah Palma Therapeutic Community merupakan satu-satunya tempat rehabilitasi narkoba milik pemerintah provinsi Jawa Barat, dan termasuk dalam lembaga yang mendirikan Indonesian Federation of Therapeutic Community (IFTC), melibatkan para mantan pecandu sebagai konselor. Pelibatan mantan pecandu narkoba sebagai konselor adiksi ini dijadikan sebagai panutan (role model) untuk memotivasi diri residen tetap fokus menjalani program rehabilitasi.Konselor adiksi Rumah Palma untuk memotivasi residennya dengan cara berbagi pengalaman semasa mereka menjalani program rehabilitasi. Pengalaman yang sama telah dialami konselor adiksi saat menderita kecanduan, membuat konselor memahami perasaan residen, sehingga mereka dapat menangani maupun berkomunikasi dengan residen sesuai kejiwaan dan emosional yang sedang dialami residen tersebut.

Program therapeutic community tidak hanya melibatkan mantan pecandu sebagai konselor tetapi keterlibatan keluarga residen sangat diperlukan untuk pemulihan. Keluarga sebagai lingkungan terdekat residen, dituntut untuk mendukung treatment yang diberikan oleh konselor. Dukungan keluarga tersebut terlihat dari adanya kegiatan yang difasilitasi oleh Rumah Palma, yakni family support group.Family support groupmerupakan pertemuan keluarga residen dankonselor untuk membicarakan kepentingan rencana treatment, lebih mendekatkan residen dengan keluarganya, dan menumbuhkan kepercayaan residen kepada keluarganya.Adanya family support groupdiharapkan menjadi suatu bentuk dukungan untuk proses komunikasi terapeutik yang dilakukan konselor adiksi dengan residen 
karena keluarga residen menjadi lingkungan terdekat bagi residen dan sumber dukungan emosional residen setelah menyelesaikan program rehabilitasi. Melalui keluarga pula penanaman sistem moral dan nilai-nilai positif dapat dibangun untuk pembentukan perilaku positif serta pertahanan diri dari penyalahgunaan narkoba kembali. Berdasarkan penjelasan tersebut peneliti memfokuskan pada "Bagaimana komunikasi terapeutik yang dilakukan konselor dalam membantu pemulihan korban penyalahgunaan narkoba?"

Tujuan dari penelitian ini diantaranya untuk menemukan metode terapi komunikasi yang digunakan konselor adiksi dalam membantu pemulihan korban penyalahgunaan narkoba di Rumah Palma Therapeutic Community, menemukan dukungan keluarga residen pada komunikasi terapeutik konselor adiksi dalam membantu pemulihan korban penyalahgunaan narkoba di Rumah Palma Therapeutic Community, dan untuk menemukan alasan mantan pecandu yang menjadi konselor adiksi dalam membantu pemulihan korban penyalahgunaan narkoba di Rumah Palma Therapeutic Community.

\section{METODE PENELITIAN}

Jenis penelitian dalam penelitian ini adalah studi kasus. Studi kasus secara umum merupakan strategi yang lebih cocok bila pokok pertanyaan suatu penelitian berkenaan dengan "how" atau "why", bila peneliti hanya memiliki sedikit peluang untuk mengontrol peristiwa-peristiwa yang akan diselidiki, dan bilamana fokus penelitian terletak pada fenomena kontemporer (masa kini) di dalam kehidupan nyata. (Yin, 2002: 1). Studi kasus dalam penelitian ini menggunakan studi kasus dengan tipe eksplanatoris. Pada kasus ini, komunikasi terapeutik konselor adiksi yang merupakan mantan pecandu narkoba dalam membantu pemulihan residen adalah kasus tunggal. Dengan eksplanatoris peneliti dapat menjelaskan mengenai bagaimana metode terapi komunikasi yang dilakukan oleh konselor adiksi dalam membantu pemulihan residen, bagaimana dukungan keluarga residen pada komunikasi terapeutik konselor adiksi dalam membantu pemulihan residen, dan alasan mantan pecandu menjadi seorang konselor adiksi dalam membantu pemulihan residen.
Teknik yang dipergunakan dalam pengumpulan data pada penelitian ini adalah observasi partisipan, wawancara mendalam, dan studi dokumentasi.Pemilihan informan kunci dilakukan dengan teknik purposive sampling, pemilihan sampel yang sesuai dengan tujuan penelitian. Nara sumber yang dijadikan key informan diambil dengan pertimbangan bahwa mereka memiliki sangkut paut dengan program rehabilitasi therapeutic community di Rumah Palma. Adapun narasumber yang dijadikan key informan dalam penelitian ini adalah: Konselor adiksi Rumah Palma Therapeutic Community, Korban penyalahgunaan narkoba atau residen, Keluarga residen yang aktif mengunjungi residen dan ikuti dalam kegiatan family support group. Peneliti juga melibatkan Kepala Perawat dan Dokter adiksi yang memiliki tanggung jawab dalam program rehabilitasi therapeutic community di Unit Napza Rumah Palma sebagai penunjang sumber data tambahan pada penelitian untuk memperkaya data dan informasi pada penelitian.

\section{HASIL DAN PEMBAHASAN}

Metode terapi komunikasi yang dilakukan konselor adiksi di Rumah Palma Therapeutic Community berupa metode konseling. Konseling di Rumah Palma Therapeutic Community merupakan terapi dasar dari program pemulihan korban penyalahgunaan narkoba. Terapi konseling tersebut terdiri dari konseling group (static group) dan konseling individu (individual counseling). Konseling terkait dengan proses komunikasi konselor dengan klien untuk menggali isu pada diri klien, dan memahami permasalahan klien baik permasalahan adiksi hingga permasalahan hidup yang menyebabkan klien ketergantungan narkoba. Metode konseling konselor adiksi tidak terlepas dari adanya komunikasi terapeutik. Hibdon, S (dalam Suryani 2006: 6) menyatakan bahwa pendekatan konseling yang memungkinkan klien menemukan siapa dirinya merupakan fokus dari komunikasi terapeutik. Melalui konseling, konselor adiksi Rumah Palma Therapeutic Community dapat menggali permasalahan dan isu diri klien serta perilaku klien, sehingga konseling dijadikan cara untuk menentukan pemberian treatment plan.

Konseling yang dilakukan konselor adiksi untuk pemahaman diri kliendapat diketahui 
dengan static group.Static group atau konseling kelompok merupakan kegiatan konseling yang berupaya dalam perubahan perilaku residen dalam menjalani program. Metode terapi ini dilakukan konselor secara rutin dan terjadwal setiap seminggu sekali dan berdurasi 30-60 menit. Static group juga dimanfaatkan untuk membantu klien mengetahui isu dirinya. Selain itu, konselor melakukan monitoring dan evaluasi treatment plan klien melalui konseling. Monitoring dan evaluasi treatment plan dilakukan agar konselor mengetahui perkembangan, serta perilaku sesungguhnya yang dimunculkan oleh klien. Kegiatan tersebut dilakukan secara bersama-sama antara para klien dan konselor, sehingga dalam setiap static konselor memberikan kesempatan klien membuat suatu goal yang harus dicapai, serta goal tersebut dapat membuat perubahan perilaku negatif pada diri klien. Perkembangan para klien yang dibahas pada saat static group tidak hanya dari pengamatan konselor dan progress klien, tetapi didasarkan pula dari hasil laporan Mayor On Duty (MOD) yang bertugas serta para brother (residen atau klien) lainnya pada saat klien menjalani aktivitas harian. Pada dasarnya perubahan perilaku para klien akan terlihat pada saat menjalani aktivitas harian selama berada di program rehabilitasi. Perilaku klien tersebut akan memperlihatkan apakah klien tersebut mampu memangkas perilaku negatif atau justru klien memperlihatkan perilaku sebenarnya, seperti kemalasan untuk melaksanakan function (tugas harian), tidak taat pada aturan, bertindak masa bodoh terhadap apa yang sedang terjadi, manipulate, guilty feeling yang menyebabkan klien menjadi pendiam, hingga kekerasan fisik karena halusinasi dan kontrol emosi yang tidak stabil. Permasalahan tersebut selanjutnya akan dibahas oleh konselor saat static group untuk mencari solusi dari permasalahan isu kliennya tersebut.

Static group yang merupakan konseling secara kelompok, membantu konselor dalam memberikan treatment dan memotivasi para kliennya. Konseling secara kelompok menumbuhkan adanya tekanan diantara sesama klien sebagai anggota static. Tekanan dari sesama klien ini merupakan tekanan positif untuk saling memotivasi dalam memangkas perilaku negatif. Melihat tekanan positif anggota yang ada pada static group sesuai dengan pendapat Smith dalam Abraham dan Shanley (1997: 195) bahwa perkembangan pribadi dapat didorong melalui dinamika kelompok. Dinamika kelompok ini merupakan perhatian konselor adiksi pada penciptaan suatu lingkungan pemulihan, dimana anggota static merasa bahwa anggota lain mempunyai keinginan yang positif pada mereka, serta mampu berempati dengan pengalaman mereka, sehingga klien akan termotivasi untuk perubahan perilaku. Sejalan dengan itu, menurut La Rossa dan Reitzes (West dan Turner, 2008: 99) dalam interaksi simbolik menjelaskan bahwa, manusia bertindak terhadap manusia lainnya berdasarkan makna yang diberikan orang lain kepada mereka. Klien saat mengikuti static group memberikan makna untuk pengalaman pemulihannya, dengan menerapkan interpretasi dari apa yang dilihat sebagai kekuatan sosial yang membentuk perilaku positif dirinya.

Konseling lainnya yang juga mendukung pemulihan residen adalah individual counseling. Individual counselingdi Rumah Palma merupakan konseling yang tidak dilakukan secara rutin. Individual counseling hanya dilakukan apabila klien membutuhkan bantuan konselor, baik saat klien mengalami suatu permasalahan pribadi, permasalahan program, maupun permasalahan kehidupannya di luar program pemulihan. Individual counseling juga dijadikan konselor sebagai cara awal untuk menentukan treatment plan pada bulan pertama klien menjalani program pemulihan. Cara ini dapat membuat konselor lebih mengenal pribadi kliennya, selain dari wawancara assessment ASI (Addiction Severity Index). Treatment plan tersebut terdiri dari program therapeutic community, cognitive behavior therapy, dan narcotic annonymius. Konselor juga lebih banyak memanfaatkan individual counseling untuk mendalami penggunaan atau substance adiksi klien, mengetahui hal-hal yang mendesak pada diri klien, meninjau perasaan takut atau kecemasan klien saat mengalami perubahan dalam diri ketika menjalani program pemulihan. Individual counseling bersifat informal, personal, serta diadik. Individual counseling menjadikan konseling yang dilakukan antara konselor adiksi dan klien lebih mendalam. Dalam individual counseling, konselor adiksi banyak menggali pribadi klien. Tidak hanya itu, konselorpun lebih memaparkan solusi berupa pemilihan pandangan atau pengarahan untuk klien dalam menyelesaikan permasalahan yang dihadapi. Solusi yang dipaparkan 
konselor adiksi merupakan bagian dari teknik konseling, yakni advice berupa saran mengenai perubahan (mengurangi atau berhenti) terhadap penggunaan zat secara jelas disampaikan konselor kepada klien dengan cara yang tidak menghakimi.

Solusi atau pandangan tersebut diperlukan bagi klien agar klien berhati-hati dalam mengambil keputusan. Namun, solusi atau pandanganyangdiberikantidakbolehdipaksakan oleh konselor adiksi kepada kliennya. Konselor adiksi hanya boleh mengarahkan pilihan-pilihan yang dapat dilakukan klien. Pengarahan untuk klien termasuk ke dalam menus (pilihan menu tentang pilihan-pilihan yang mengarahkan diri sendiri) dan responsibility (tanggung jawab pada diri klien untuk membuat pilihan bagi dirinya). Jika konselor memberikan solusi untuk pemecahan masalah klien, klien yang notabene seorang pecandu yang memiliki pribadi adiksi tidak akan memiliki kemampuan untuk mencari jalan keluar untuk permasalahan klien sendiri. Klienpun tidak terlatih bersikap dewasa dalam memutuskan sesuatu. Selain itu, dengan memaksakan kehendak pribadi konselor bagi klien telah menyalahi kode etik. Terkait dengan itu, menurut Corey (1988: 429) konselor membantu klien menemukan penyelesaianpenyelesaiannya sendiri dan membantu klien agar menyadari kebebasannya untuk bertindak, bukan menjauhkan klien dari kesempatan mengambil resiko melaksanakan kebebasannya. Tugas konselor adalah membantu klien agar secara mandiri membuat pilihan-pilihan dan agar memiliki keberanian untuk menerima konsekuesi-konsekuensi dari pilihan-pilihannya (Corey, 1988: 430). Konselor adiksi Rumah Palma telah memperlihatkan bahwa pemberian pandangan atau arahan atas permasalahan klien merupakan bagian dari treatment, agar klien mengalami pembelajaran dan lebih bersikap dewasa serta mandiri saat mengalami permasalahan.

Metode terapi komunikasi yang dilakukan para konselor adiksi Rumah Palma bertujuan sebagai perubahan dan pemangkasan perilaku negatif, yang tentunya dapat mencerminkan tujuan dari komunikasi terapeutik. Adapun tujuan dari komunikasi terapeutik adalah: (1) Membantu klien untuk memperjelas dan mengurangi beban perasaan dan pikiran serta dapat mengambil tindakan untuk mengubah situasi yang ada bila pasien percaya pada hal- hal diperlukan, (2) Mengurangi keraguan, membantu dalam hal mengambil tindakan yang efektif dan mempertahankan kekuatan egonya, (3) Mempengaruhi orang lain, lingkungan fisik dan dirinya sendirinya dalam peningkatan derajat kesehatan, dan (4) Mempererat hubungan atau interaksi antara klien dengan terapis (tenaga kesehatan) secara profesional dan proposional dalam rangka membantu penyelesaian masalah klien (Mundakir, 2006: 117).

Komunikasi terapeutik yang dilakukan konselor adiksi melalui metode terapi konseling pun tidak terlepas dari tahapan komunikasi terapeutik. Tahapan komunikasi tersebut menurut Stuart G. W dalam Damaiyanti (2008: 29-30) terdiri dari empat tahap, yakni tahap persiapan atau prainteraksi, tahap perkenalan atau orientasi, tahap kerja dan tahap terminasi.

Di tahap prainteraksi atau tahap persiapan ini konselor menggali perasaan, fungsi, dan ketakutan diri. Pada tahap ini konselor juga menganalisis kekuatan profesional diri dan keterbatasanan klien. Mengumpulkan data tentang klien, serta merancang strategi untuk pertemuan pertama dengan klien. Di tahap perkenalan, konselor pada tahap ini menentukan mengapa klien mencari pertolongan, menyediakan kepercayaan, menunjukkan penerimaan, dan komunikasi terbuka. Selain itu, konselor merumuskan kontrak timbal balik bersama klien. Tugas selanjutnya, konselor menggali pikiran, perasaan, dan tindakan. Mengindentikasi masalah klien serta terakhir merumuskan tujuan dengan klien.

Selanjutnya tahap kerja. pada tahap ini konselor menggali stressor yang sesuai/ relevan, mendorong perkembangan insight klien dengan penggunaan mekanisme koping instruktif. Pada tahap ini dituntut kemampuan konselor dalam menangani tingkah laku yang dipertahankan oleh klien (resistence). Terakhir, tahap terminasi.Tahap terminasi merupakan akhir dari pertemuan konselor-klien. Pada tahap ini konselor menyediakan realitas perpisahan, melihat kembali kemajuan dari terapi dan pencapaian tujuan, dan saling mengeksplorasi perasaan adanya penolakan, kehilangan, sedih dan marah, juga tingkah laku yang berkaitan.

Tahap prainteraksi yang dilakukan para konselor adiksi adalah mengenali calon klien berdasarkan hasil ASI dan selanjutnya diadakan staff meeting untuk memilih konselor yang tepat dalam menangani klien. Konselor yang sanggup 
menangani klien telah mengetahui kemampuan diri seperti membangun kedekatan emosional dengan klien serta mampu melakukan krisis intervensi kepada klien. Konselor mengumpulkan data klien melalui biodata, substance penggunaan, mengajak berbincang klien di saat waktu senggang, dan menentukan waktu pertemuan untuk static counseling atau individual counseling. Tahap perkenalan yang dilakukan konselor adiksi adalah menggali isu, perasaan, dan permasalahan klien melalui konseling static dan individual. Konselor pada tahap ini membangun hubungan baik dan menjalin kedekatan seperti keluarga. Konselor pun membina rasa saling percaya dengan klien, hingga membuat klien merasa nyaman. Konselor adiksi pun menerima klien apa adanya dengan menerima segala perilaku negatif klien, kejujuran dan keterbukaan klien. Tak hanya itu, konselor bersikap terbuka kepada klien dalam memaparkan latar belakang konselor agar klien merasa konselor terbuka berkomunikasi pada dirinya. Dari kedekatan dengan klien, konselor selanjutnya menentukan treatment plan yang sesuai dengan kebutuhan klien.

Tahap kerja yang dilakukan konselor adiksi kepada klien adalah menanyakan alasan klien mengikuti program rehabilitasi, memastikan kesungguhan klien menjalani rehabilitasi, memperdalam permasalahan adiksi, menyelesaikan isu diri klien yang muncul kepermukaan terlebih dahulu, mengevaluasi dan mengkonfrontasi perilaku klien saat menjalani aktivitas harian, memberikan motivasi dan krisis intervensi bagi klien yang kurang bersemangat dan telah melakukan kesalahan. Selain itu, konselor memberi kesempatan bagi klien menentukan goals setting apa yang harus dicapai baik selama mengikuti program maupun saat telah menyelesaikan program. Goals setting berupa action plan yang harus dicapai klien, seperti keinginan untuk sekolah, kursus, bekerja, dan memiliki usaha. Selain itu dalam goals setting harus ada recovery plan, segala sesuatu kegiatan yang berhubungan dan dapat menunjang proses pemulihan klien. Tahap terakhir dari konseling yang dilakukan konselor adalah tahap terminasi. Pada tahap ini konselor menanyakan pemahaman klien tentang program, perasaan klien tentang hubungan personal dengan konselor, pemahaman tentang apa yang dirasakan serta yang didapatkan klien dari pemilihan keputusan untuk pemecahan masalah.
Konselorpun mengevaluasi pencapaian goals setting klien, respons klien setelah diberikan pandangan, mengevaluasi coping skill serta perubahan perilaku klien, hingga mengevaluasi tujuan konseling. Jika konseling tidak berhasil dan treatment yang diberikan tidak bekerja pada diri klien, konselor menentukan kembali komposisi treatment plan dan assessment ulang. Selain itu konselor meminta bantuan konselor lain yang mempunyai kecocokan dengan klien bersangkutan.

Baik static counseling maupun individual counseling memerlukan jalinan hubungan yang baik antara konselor adiksi dan residen sebagai klien. Menurut Saam (2013: 12) langkahlangkah dalam menciptakan hubungan yang baik dengan klien adalah menerima klien secara ikhlas, menumbuhkan kepercayaan klien, dan mewujudkan keterbukaan diri. Fakta di lapangan terlihat bahwa konselor adiksi di Rumah Palma Therapeutic Community yang membangun hubungan baik dapat mempermudah kedekatan dengan klien. Kedekatan dengan klien agar konselor dapat meminimalisir kesalahan dalam pemberian treatment plan. Klien yang merupakan pecandu narkoba memiliki pribadi yang rumit. Seperti yang diakui para konselor adiksi Rumah Palma, sebagai pecandu narkoba klien memiliki pribadi adiktif diantaranya, manipulated, bertopeng, tertutup, malas, dan tidak mampu mengatasi suatu tekanan. Kedekatan dengan klien ini dapat memunculkan kepercayaan dan keterbukaan pada diri klien. Dalam menciptakan kepercayaan dan keterbukaan klien, konselor adiksi benar-benar menerima klien secara ikhlas dan apa adanya.

Konselor di Rumah Palma pun selalu memposisikan diri sebagai bagian dari keluarga klien, seperti ayah, kakak, maupun sahabat. Posisi diri konselor sebagai keluarga klien, menunjukkan karakteristik helper yang mampu menerima klien apa adanya, jika seseorang merasa diterima maka dia akan merasa aman dalam menjalin hubungan interpersonal (Suryani, 2006: 19). Konsep kekeluargaan juga dapat menumbuhkan kepercayaan pada diri klien, bahwa konselor di Rumah Palma dapat membantu mereka lepas dari ketergantungan narkoba dan merubah perilaku adiktif yang negatif. Adanya kepercayaan klien pada konselor, membuat klien terbuka dan tidak segan untuk bercerita apa saja pada konselornya. Adanya hubungan baik yang 
terjalin menciptakan makna pemulihan klien melalui simbol kedekatan. Kedekatan yang terjalin dapat mewujudkan kepercayaan, kenyamanan dan keterbukaan pada diri klien untuk menjalani program pemulihan.

Adanya kepercayaan klien pada konselor, membuat klien terbuka dan tidak segan untuk bercerita apa saja pada konselornya. Kepercayaan klien tersebut dijadikan konselor sebagai cara menggali isu diri klien untuk menentukan treatment plan. Kedekatan yang terjalin pun membantu konselor mengetahui isu mana yang akan terlebih dahulu diselesaikan. Tak hanya itu, konselor pun mudah memberikan tujuan-tujuan yang harus dicapai oleh klien sebagai bentuk treatment. Berdasarkan dengan fakta lapangan tersebut memperlihatkan konselor adiksi Rumah Palma memiliki prinsip dasar helper, menurut Struat (1998) dalam Suryani (2006: 15) komunikasi yang dilakukan oleh helper dan klien harus dapat menumbuhkan rasa saling percaya sebelum menggali permasalahan dan memberikan alternatif dalam pemecahan masalah. Hubungan antara helper dan klien merupakan kunci dari komunikasi terapeutik. Adanya hubungan baik yang terjalin menciptakan makna pemulihan klien melalui simbol kedekatan. Kedekatan yang terjalin dapat mewujudkan kepercayaan, kenyamanan dan keterbukaan pada diri klien untuk menjalani program pemulihan. Cara tersebut menjadi simbol yang mereka pertukarkan dalam interaksi saat konseling maupun di luar konseling. Mead menekankan dasar intersubjektif dari makna, makna ada hanya ketika orang-orang memiliki interpretasi sama mengenai simbol yang mereka pertukarkan dalam interaksi (West dan Turner, 2008: 100).

Proses komunikasi terapeutik yang dilakukan konselor dengan klien tidak terlepas dari penggunaan komunikasi verbal dan nonverbal. Adapun bahasa yang digunakan konselor dalam berkomunikasi dengan klien adalah bahasa Indonesia yang informal. Bahasa yang digunakan disesuaikan dengan kemampuan klien mengerti suatu bahasa. Konselor dalam berbicara mencampurkan bahasa prokem saat konseling dengan klien maupun saat berinteraksi di luar sesi konseling sebagai bentuk kedekatan layaknya keluarga, sehingga tidak ada batasan antara konselor dan klien. Tak hanya bahasa Indonesia yang menjadi bahasa keseharian mereka, bagi konselor yang berasal dari Bandung, ketika mereka mendapatkan klien berasal dari daerah yang sama, konselor tidak sungkan menggunakan bahasa Sunda. Rumah Palma sebagai komunitas terapi tentu saja memiliki persamaan bahasa atau istilah yang digunakan di dalam komunitas tersebut. Istilah ataujargon therapeutic community sering mereka gunakan pada saat konseling ataupun berinteraksi dalam kesehariannya.

Jargon therapeutic community

menggunakan bahasa Inggris, karena therapeutic community merupakan pendekatan pemulihan narkoba yang berasal dari Amerika Serikat. Istilah therapeutic community pun digunakan untuk menamai kegiatan harian yang harus dilakukan klien, hingga penamaan treatment plan yang harus dijalani klien. Menurut Stuart, G.W., (dalam Suryani, 2006: 45) kata-kata adalah alat atau simbol yang dipakai untuk mengekspresikan ideatau perasaan, membangkitkan respons emosional atau mengurai objek, observasi, dan ingatan. Melihat dari fungsi kata-kata, saat konseling beberapa konselor adiksi Rumah Palma menggunakan istilah therapeutic community yang berasal dari unwritten philosophies sebagai pemahaman tentang pembentukan perilaku maupun memotivasi klien dalam menjalani program. Unwritten philosophies sebagai simbol yang bermakna, menurut pandangan Mead apabila kita memiliki simbol-simbol yang bermakna, kita berkomunikasi dalam arti sesungguhnya (Mulyana, 2013: 78). Unwritten philosophies yang selalu dijunjung tinggi oleh konselor serta klien yakni, honesty, responsibility, gratefull, dan patience. Kata-kata tersebut selalu ditanamkan konselor kepada klien, agar klien dalam berperilaku memiliki kejujuran, selalu tanggung jawab dengan perbuatan yang dilakukan, selalu bersyukur, dan bersabar menjalani program maupun menghadapi permasalahan diri. Sejalan dengan pandangan Mead bahwa suatu simbol disebut signifikan atau memiliki makna bila simbol itu membangkitkan pada individu yang menyampaikannya respons yang sama seperti yang juga akan muncul pada individu yang dituju (Mulyana, 2013: 78). Unwritten philosophies sebagai jargon therapeutic community dapat menjadi stimulator bagi residen untuk melakukan tindakan yang jujur, bertanggungjawab, penuh dengan rasa syukur, dan bersabar dalam menjalani proses pemulihan. 
Konselor tidak hanya menggunakan simbol verbal untuk menyampaikan suatu pesanselama proses konseling terjadi. Simbol nonverbal disertai konselor sebagai bentuk penekanan simbol verbal. Konselor adiksi Rumah Palma untuk menangani klien, pertama kali mereka sangat memperhatikan penampilan fisik mereka. Penampilan yang ditampilkan terlihat dari pakaian yang digunakan adalah pakaian yang sederhana namun berwibawa. Konselor banyak menggunakan kontak mata dengan klien sebagai bentuk penekanan pesan yang berupa arahan perubahan perilaku klien dalam proses konseling. Kontak mata pun digunakan pada saat melakukan konfrontasi dengan klien, apabila klien berbohong maka klien biasanya tertunduk, tidak berani melakukan kontak mata dengan konselor saat menjawab pertanyaan. Kesiapan konselor dalam menerima klien terlihat pada body language yang ditampilkan, seperti gerakan tangan sebagai penegasan pesan, posisi duduk yang condong ke arah klien, serta posisi badan yang siap mendengarkan klien bercerita. Ekspresi wajah pun ditampilkan konselor sebagai bentuk antusias mendengarkan permasalahan klien dan menggali isu diri klien. Selain itu, konselor memberikan rasa empati dengan memberikan sentuhan. Sentuhan yang sering diberikan konselor kepada klien adalah sentuhan di pundak sebagai bentuk motivasi dan penyemangat bagi klien saat dalam keadaan menurun. Pelukan hangat diberikan konselor kepada klien sambil bersalaman sebagai tanda kedekatan yang terjalin diantara mereka. Pelukan dilakukan ketika konselor baru mengenal klien ataupun saatklien melakukankesalahan. Pelukan dilakukan baik dengan konselor maupun sesama residen. Menurut Stuart G. W. (1998) sentuhan penting dilakukan pada saat klien merasa sangat sedih. Sentuhan pada situasi ini mempunyai arti empati. Sentuhan juga dapat menunjukkan arti "Saya peduli". Simbol nonverbalpun digunakan sebagai bentuk keyakinan dan kesiapan konselor melayani klien untuk berkonseling. Selain itu, simbol nonverbal juga digunakan untuk melihat respons dari klien saat proses konseling terjadi.

Metode terapi komunikasi yang dilakukan konselor adiksi Rumah Palma harus didukung pula oleh keterlibatan keluarga klien. Keterlibatan keluarga pada program rehabilitasi dengan pendekatan therapeutic community sangat diperlukan sebagai pendukung treatment yang diberikan konselor kepada residen. Seperti yang diutarakan U.S. National Institute On Drug Abuse (2011: 239) bahwa keterlibatan keluarga bukanlah model terapi yang spesifik, riset menunjukkan bahwa keterlibatan keluarga dalam terapi menguatkan hasil terapi itu sendiri. Dukungan dari keluarga kepada klien sangat diperlukan terutama mengenai bagaimana sikap dan pola pikir keluarga kepada anak yang sedang menjalani program rehabilitasi. Sikap dan pola pikir keluarga ini menguatkan hasil treatment sebagai bentuk dukungan komunikasi terapeutik yang dilakukan konselor. Dukungan keluarga tersebut berupa komitmen keluarga kepada treatment yang diberikan konselor, keaktifan keluarga mengikuti kegiatan family support group dan family dialog.

Komitmen keluarga pada treatment yang diberikan konselor bertujuan untuk memberikan pemahaman keluarga atas program pemulihan yang dijalani residen. Komitmen keluarga pada treatment residen juga sebagai bentuk penegasan atas tanggung jawab orang tua saat anak mengalami kekambuhan dan tidak menyelesaikan program sampai tahap akhir. Komitmen keluarga mendukung treatment yang diberikan konselor dapat meningkatkan motivasi residen untuk pulih. Terutama dengan adanya kesadaran keluarga bahwa penyalahgunaan narkoba yang dialami anaknya terkait dengan masalah-masalah dalam keluarga. Kebanyakan keluarga yang memasukkan anaknya ke Rumah Palma memiliki rasa co-dependensi kepada anaknya. Co-dependensi ini membuat anak tidak dapat mandiri dan dewasa dalam bersikap selama menjalani treatment. Corey (1990: 23) mengemukakan bahwa anak memperoleh rasa memiliki kekuatan, kemandirian, dan otonomi. Jika orang tua berbuat terlalu banyak bagi anaknya, ini berarti bahwa si orang tua mengajari anaknya itu untuk tidak memiliki kesanggupan fungsi diri.

Selain itu, terdapat pula sikap orang tua yang tidak menerima memiliki anggota keluarga seorang pecandu. U.S. Center For Substance Abuse Treatment (2011) mengemukakan, keluarga disfungsi sering juga memiliki hubungan yang renggang dan tidak saling percaya, menderita kehilangan identitas individu, dan mengalami terputus-putusnya perkembangan emosional, terutama pada anakanak dan remaja. Hal tersebut memperlihatkan bahwa keluarga memberi pengaruh atas perilaku residen berdasarkan apa yang 
mereka terima dari perspektif orang lain yang dianggap penting. Keluarga menurut konsep Mead merupakan bagian dari perkembangan diri individu. Perkembangan diri secara jelas diamati pada anak-anak. Tahap permainan (play stage) adalah perkembangan pengambilan peran bersifat elementer yang memungkinkan anakanak melihat diri mereka sendiri dari perspektif orang lain yang dianggap penting (significant others), khususnya orang tua (Mulyana, 2013: 87). Adanya sikap co-dependensi orang tua dan penolakan keluarga saat anaknya mengalami permasalahan adiksi membuat perilaku residen terbatas dalam perspektif yang negatif mengenai dirinya.

Sikap co-dependensi orang tua residen pada saat residen anak-anak membawa pengaruh pada perilaku residen yang tidak bisa mandiri, dewasa, dan tidak memiliki tanggung jawab pribadi saat mereka melakukan suatu kesalahan di lingkungan sosialnya. Penolakan keluarga yang diterima residen menjadikan residen memiliki pandangan diri bahwa mereka individu yang tidak dapat dipercaya untuk melakukan pemangkasan pada perilaku negatifnya. Dengan sikap keluarga tersebut maka diperlukan partisipasi aktif keluarga mengikuti treatment yang diberikan konselor adiksi melalui family support group dan family dialog. Treatment ini dilakukan agar keluarga mengerti dan memahami cara mengatasi residen saat di rumah dan memecahkan permasalahan yang dialami anaknya. Family support group berfungsi sebagai motivasi keluarga agar mampu menerima keadaan anaknya yang seorang pecandu. Karena tidak sedikit orang tua yang memang merasa sendiri ketika anaknya sebagai pecandu. Family support group juga berisi pemberian materi untuk orang tua dalam mendukung konselor untuk membantu pemulihan anaknya sebagai residen. Lebih mendalam, konselor adiksi memberi pemahaman program pemulihan pada keluarga melalui family dialog. Adanya kegiatan tersebut dijadikan cara konselor untuk memberikan pengenalan program dan pengarahan agar keluarga melakukan penyesuaian kepada anak, yang meliputi cara berkomunikasi, aturan-aturan di keluarga, cara memecahkan permasalahan yang dihadapi keluarga, dan aktif menjadi sumber informasi bagi konselor. Terutama terkait dengan peran konselor yang setelah residen menyelesaikan program akan dikembalikan pada keluarganya, sehingga keluarga mampu mempertahankan pemulihan residen. Sejalan dengan hal itu, sesuai dengan penjelasan dalam Paduan Terapi Gangguan Penggunaan Zat-Rawatan Berkelanjutan untuk Profesional Adiksi (2011: 240), pendekatan berbasis keluarga dapat mendorong anggota keluarga untuk memberikan dukungan jangka panjang. Begitu klien mulai pulih, anggotaanggota keluarga perlu mengambil tangggung jawab penuh untuk pemulihan emosi, fisik, dan spiritual mereka.

Berkaitan dengan family dialog, keluarga pun diberikan treatment dalam caraberkomunikasi. Keluarga dituntut untuk berkomunikasi sesuai arahan konselor adiksi. Komunikasi yang dilakukan keluarga dengan klien baik melalui telepon, kunjungan dan saat home leave dapat memperbaiki hubungan keluarga yang sebelumnya mengalami disfungsi. Komunikasi yang diterapkan keluarga sesuai dengan arahan oleh konselor, seperti tidak berlaku malu dengan kehadiran klien, tidak mengungkit masa lalu klien, tidak menyudutkan klien, serta tidak bersikap keras kepada klien. Komunikasi tersebut dapat menumbuhkan rasa kepercayaan keluarga kepada klien. Kepercayaan keluarga pada klien semasa menjalani program dapat mendukung proses komunikasi terapeutik konselor dalam pembentukan perilaku positif. Dengan demikian keaktifan keluarga dalam berbagai kegiatan yang mendukung pemulihan dapat merubah cara pandang keluarga kepada klien. Pandangan keluarga, khususnya orang tua yang memandang anaknya negatif, setelah mengikuti program rehabilitasi orang tua memiliki pandangan baru akan kemampuan anak dapat lepas dari ketergantungan, dan memangkas perilaku negatif adiksi. Dukungan keluarga merupakan bagian dari peran significant others dalam perkembangan diri klien. Keluarga klien dalam konsep Mead merujuk pada significant others, yang membentuk atau mempengaruhi diri sebagaimana orang-orang itu dipengaruhi kehadiran diri tersebut (Mulyana, 2013: 80).

Adanya pemahaman keluarga tentang permasalahan adiksi, sikap keluarga yang tidak berlaku malu, tidak mengungkit masa lalu, tidak berlaku keras, tidak menyudutkan, dan tidak langsung menuruti keinginan anak, hal tersebut dapat memberi pengaruh pada perasaan residen akan penerimaan diri 
residen, selain dari pengaruh pada komunitas terapi sebagai kelompok rujukan. Keluarga sebagai significant others ini akan membentuk perilaku klien untuk mendapatkan penerimaan sosial sebagai pecandu yang bisa pulih setelah menjalani program rehabilitasi. Keluarga juga mempersiapkan perkembangan diri residen untuk kembali berinteraksi generalized others. Generalized others ini juga akan membentuk residen melihat dirinya dari berbagai perspektif. Fakta saat pengamatan berlangsung menurut para informan, kebanyakan generalized others masih memberikan perspektif yang negatif kepada residen selaku pecandu yang menjalani rehabilitasi. Ketidakpercayaan generalized others pada para residen membuat mereka mencari pengakuan saat berinteraksi di masyarakat.

Pemulihan pencandu narkoba dengan pendekatan therapeutic community pada dasarnya membutuhkan keterlibatan para recovering addict atau mantan pecandu narkoba sebagai konselor adiksi. Pelibatan mantan pecandu dapat membantu keberhasilan dari treatment dan program rehabilitasi yang diberikan kepada residen. Semua konselor adiksi di Rumah Palma merupakan mantan pecandu dari berbagai tempatrehabilitasi narkoba, termasuk lulusan Rumah Palma Therapeutic Community. Salah satu alasan para mantan pecandu narkoba memilih mengabdi di dunia adiksi sebagai konselor adalah dapat menjadi role model bagi para residen. Diakui beberapa residen dan dokterbahwa mereka menjadikan konselornya atau brother sebagai role model dalam membantu pemangkasan perilaku negatif dirinya. Menurut Brammer (1985) dalam (Mappiare, 1992: 96) bahwa kemampuan para helper sebagai "teladan" diperlukan pula dalam proses helping. Para helper harus dapat menunjukkan kemampuan melihat inti masalah dengan tajam, cepat dan menampak mempunyai rasa percaya diri yang mapan. Rasa percaya diri yang mapan ini tentu saja bagi konselor adiksi Rumah Palma adalah menjadi seorang yang apa adanya dan terbuka kepada klien. Gerad Corey (1988: 389) menyebutkan bahwa jika terapis menjadi model keotentikan dengan menjadi apa adanya, terbuka, dan terlibat dalam penyingkapan diri yang layak dan fasilitatif, maka dia bisa mengantisipasi bahwa klien akan mengintegrasikan ke dalam dirinya sendiri sifat-sifat yang sama. Hal ini sesuai dengan fakta dilapangan bahwa residen Rumah Palma menjadikan konselor adiksi sebagai role model untuk memotivasi perubahan perilaku ke arah yang positif, karena memiliki kesamaan dengan mereka.

Kemampuan menjadi seorang role model ini menjadi bagian dari kajian dalam interaksi simbolik, yang dapat terlihat pada asumsi konsep diri memberikan motif penting untuk perilaku (West dan Turner, 2008: 102). Mead berpendapat bahwa karena manusia memiliki diri, mereka mekanisme untuk berinteraksi dengan dirinya sendiri. Memiliki diri memaksa orang untuk mengonstruksi tindakan dan responsnya, daripada sekedar mengekspresikannya (West dan Turner, 2008: 102). Fakta di lapangan memperlihatkan bahwa konselor adiksi yang memiliki konsep diri yang baik, yakin akan kemampuan sebagai seorang penolong bagi residen, maka akan membantu dirinya memiliki kepercayaan diri sebagai konselor adiksi meskipun mereka seorang junkie.

Secara personal mantan pecandu yang menjadi konselor adiksi Rumah Palma, mengemukakan bahwa mereka memilih menjadi konselor di bidang adiksi karena memiliki rasa ingin membantu sesamanya. Rasa ingin membantu sesama pecandu narkoba ini sebagai bentuk kepedulian mereka kepada banyaknya kasus penyalahgunaan narkoba yang belum dapat tertangani secara benar. Keinginan untuk membantu para pecandu lain, bagi mereka timbul dari dalam diri karena telah merasakan pernah hidup di dunia hitam.Diakui para informan kunci konselor adiksi, mereka ingin membantu karena mereka telah memahami bagaimana perilaku pecandu, perasaan pecandu, pola pikir pecandu, dan penderitaan pecandu baik saat masih menjadi pecandu maupun saat menjalani program rehabilitasi therapeutic community.

Berkaitan dengan munculnya keinginanuntuk membantu sesama pecandu narkoba, serta adanya prinsip "man helping man to help himself", konselor Rumah Palma mempunyai kedekatan emosional yang lebih dengan residen. Kedekatan emosional yang terjalin dapat mendukung proses pemberian treatment plan kepada residen. Kedekatan emosional yang terbina antara mantan pecandu dan residen lebih cepat ketimbang dengan orang yang bukan berasal dari mantan pecandu. Hal ini tercermin dari adanya rasa empati yang dimiliki 
para konselor Rumah Palma. Rasa empati yang dimiliki konselor Rumah Palma lebih kuat ketimbang empati perawat. Para konselor Rumah Palma sebagai mantan pecandu lebih cepat membangun hubungan akrab dengan residen dan lebih mengetahui isu dalam diri residen, sehingga lebih cepat menangani permasalahan yang dialami residen. Kedekatan emosional yang terjalin pun dapat mendukung keberhasilan treatment yang diberikan. Hal ini tercermin dari cara berkomunikasi saat konseling dengan residen yang tidak prosedural, tidak kaku, dan tidak formal. Dengan komunikasi yang seperti itu residen akan merasakan kenyamanan berbagi cerita yang mereka alami selama menjalani program, serta treatment yang diberikan lebih bisa diterima oleh mereka.

Selanjutnya, alasan para mantan pecandu menjadi konselor adiksi di Rumah Palma terkait dengan mempertahankan bentuk recovery maintenance. Dengan kata lain para mantan pecandu setelah menyelesaikan program rehabilitasi mencari lingkungan yang "aman" bagi pemulihannya. Diakui beberapa informan kunci, para mantan pecandu menghindari stigma di keluarga dan masyarakat dengan memilih sebagai konselor di tempat rehabilitasi. Bagi beberapa keluarga yang memiliki anggota keluarga sebagai junkie, mereka masih memiliki stigma bahwa recovering addict tetaplah junkie dengan perilaku negatifnya. Dengan menjalani aktifitas konselor, mantan pecandu menyadari bahwa kapasitas mereka hanya sesuai di lingkungan yang aman, yakni lingkungan rehabilitasi. Berada di lingkungan rehabilitasi menghindari mereka dari relapse. Alasan junkie sebagai konselor untuk recovering maintainance terkait dengan cerminan diri mereka ketika berinteraksi dengan masyarakat. Dalam interaksi simbolik, Mead menegaskan diri sebagai kemampuan untuk merefleksikan diri kita dari perspektif orang lain (West dan Turner, 2008: 105). Masih adanya stigma negatif dari masyarakat kepada mereka, dan adanya harapan dari orang tua sebagai orang terdekat membuat konselor mengetahui dirinya sebagai pribadi yang masih rentan terhadap perilaku adiksi, hal tersebut merupakan bentuk refleksi diri mantan pecandu dari perspektif orang lain di sekitarnya.

Keberadaan mantan pecandu mengabdi sebagai konselor adiksi Rumah Palma karena mereka mengaplikasikan bagian dari unwritten philosophies therapeutic community, yakni "you can't keep it unless you give it away". Dijelaskan dalam buku Metode Therapeutic Community (2009: 171) bahwa para pecandu dalam periode pemulihan awal sering menerima nasihat atau bantuan ketika ia bergulat dengan perubahanperubahan pemulihan awal. Dia mencapai pemulihannya dari kecanduan oleh upaya untuk menerapkan apa yang telah ia pelajari dari orang lain yang telah melalui jalan yang sama. Untuk menjaga ketenangan hati dan apa yang ia terima dari orang lain, sangat penting bahwa ia memberi kembali atau mengajarkan kepada orang lain. Berdasarkan penjelasan tersebut, para mantan pecandu menjadi konselor adiksi dan berada di lingkungan rehabilitasi sematamata menjaga ketenangan hati dari stigma negatif di masyarakat. Lingkungan rehabilitasi selalu mengingatkan para konselor adiksi untuk kembali mengajarkan apa yang telah dipelajari sebagai orang dengan latar belakang recovering addict.

Alasan mantan pecandu yang menjadi konselor adiksi di Rumah Palma dapat dikaji melalui teori looking glass self (cerrmin diri). sebagai mantan pecandu, konselor adiksi memiliki kemampuan mengambil peran, yakni membayangkan diri dari pandangan residen maupun masyarakat. Cooley (1972) dalam West dan Turner (2008: 106) meyakini bahwa kita membayangkan bagaimana kita terlihat di mata orang lain.Hal ini ditunjukkan oleh mantan pecandu yang memilih mengabdi di lingkungan rehabilitasi sebagai konselor adiksi. Mereka telah membayangkan pandangan masyarakat yang masih sulit menerima keberadaan junkie saat berintegrasi ke masyarakat. Dengan kembalinya ke lingkungan rehabilitasi sebagai konselor adiksi, mereka justru dapat membayangkan dirinya sebagai orang yang berhasil pulih dari ketergantungan. Hal ini dikarenakan mereka dijadikan role model bagi para residen di Rumah Palma dalam membantu proses pemulihan.

Seperti yang diyakini Cooley (1972) bahwa kita membayangkan penilaian mereka mengenai penampilan kita (West dan Turner, 2008: 106). Meskipun mantan pecandu, konselor adiksi yang dijadikan role model oleh residennya akan menampilkan karisma, penuh perhatian, dan perilaku positif. Selain sikap yang ditampilkan, konselor juga memperlihatkan penampilan dari pakaiannya yang rapi dan bersih sebagai wujud kesiapan 
membantu residen. Penampilan sebagai role model tersebut mendapatkan penilaian positif yang berupa rasa respect dan penerimaan diri residen dalam menjalani program pemulihan. Lebih lanjut, Cooley (1972) menyatakan prinsip terakhir bahwa kita merasa tersakiti atau bangga berdasarkan perasaan pribadi ini (West dan Turner, 2008: 106). Konselor adiksi merasa bangga berdasarkan perasaan pribadi yang memiliki panggilan hati untuk membantu residen di Rumah Palma. Dengan kebanggaan yang dimilikinya membuat konselor adiksi yang merupakan mantan pecandu lebih memahami perilaku dan penderitaan yang dialami residen. Hal ini terkait dengan pengalaman dirinya sebagai junkie yang juga pernah mengikuti program therapeutic community. Kesamaan pengalaman sebagai junkie menimbulkan rasa empati yang lebih kepada para residen. Rasa empati ditunjukkan melalui adanya kedekatan secara emosional diantara konselor dan residen. Melalui kedekatan tersebut residen lebih mudah terbuka menceritakan permasalahannya kepada konselor.

Perasaan bangga diri konselor adiksi akan pengalaman sebagai junkie, membuat konselor tidak hanya memiliki kedekatan emosional, akan tetapi konselor mampu memberi contoh nyata secara objektif dalam memberikan treatment maupun pandangan-pandangan terhadap solusi atas permasalahan residen. Contoh nyata berdasarkan pengalaman pribadi dijadikan cara konselor untuk memangkas perilaku negatif dan sebagai bentuk memotivasi residen dalam menjalani program pemulihan. Berdasarkan teori looking glass self, mantan pecandu dapat mengetahui kemampuan diri sebagai konselor adiksi di Rumah Palma dari cara residen memberi respons, melalui perlakuannya, penilaiannya, dan memberi label sebagai role model kepada para mantan pecandu yang menjadi konselor adiksi.

\section{SIMPULAN}

Metode terapi komunikasi yang dilakukan konselor adiksi di Rumah Palma Therapeutic Community berupa metode konseling. Konseling tersebut terdiri dari konseling group (static group) dan konseling individu (individual counseling). Dalam metode terapi komunikasi konselor adiksi didasari oleh jalinan hubungan yang baik. Hubungan tersebut menimbulkan kedekatan, kenyamanan, dan kepercayaan diantara konselor dan residen. Metode terapi komunikasi ini pun tidak terlepas dari penggunaan komunikasi verbal maupun nonverbal. Komunikasi verbal yang digunakan konselor adalah penggunaan bahasa Indonesia keseharian, bahasa daerah Sunda, dan jargonjargon therapeutic community. Sedangkan komunikasi nonverbal yang digunakan konselor adiksi terdiri dari penampilan, kontak mata, ekpresi wajah, body language, sentuhan, dan pelukan.

Dukungankeluargaresidenpadakomunikasi terapeutik konselor adiksi dalam membantu pemulihan korban penyalahgunaan narkoba di Rumah Palma, yakni berupa komitmen keluarga kepada treatment yang diberikan konselor, keaktifan keluarga mengikuti kegiatan family support group dan family dialog.

Alasan mantan pecandu menjadi konselor adiksi dalam membantu pemulihan korban penyalahgunaan narkoba di Rumah Palma Therapeutic Community adalah sebagaimantan pecandu yang berhasil pulih dari ketergantungan narkoba, mereka dapat dilibatkan sebagai role model (model panutan) bagi para residen. Konselor adiksi Rumah Palma yang semuanya merupakan mantan pecandu beralasan bahwa secara personal mereka memiliki kepedulian dan rasa ingin membantu sesama pecandu narkoba. Dengan menjadi konselor adiksi, mereka sebagai mantan pecandu dapat mempertahankan recovery maintainance setelah mereka menyelesaikan program.

Berdasarkan penelitian yang telah dilakukan adapun saran yang dapat membantu perbaikan untuk metode terapi melalui komunikasi terapeutik konselor adiksi adalah diharapkan dapat menyempatkan waktu yang lebih banyak untuk proses konseling, terutama saat static group, agar klien dapat lebih memahami tujuan dari konseling kelompok. Konselor adiksi di Rumah Palma Therapeutic Community juga sebagai mantan pecandu diharapkan memperluas dan wawasan mengenai komunikasi dan konseling, dengan cara mengikuti pelatihan-pelatihan konselor yang bersertifikat, sehingga konselor tidak hanya membantu pemulihan residen dari pengalaman yang telah dialami saja, akan tetapi secara profesional juga dapat mengaplikasikan pemulihan residen berdasarkan teori dan teknik konseling yang telah mereka pelajari. 


\section{DAFTAR PUSTAKA}

Abraham, C.\& Shanley, A. (1997). Psikologi sosial untuk keperawatan. Terjemahanan: Leon I Sally M. Jakarta: EGC.

BNN Pusat Terapi dan Rehabilitasi. (2009). Metode therapeutic community. Jakarta: BNN

Brammer. (1993). The helping relationship: process and skills. ed ke-5. USA: Allyn dan Bacon.

Corey, G. (1988). Teori dan praktek konseling dan psikoterapi. Terjemahan E. Koeswara. Bandung: Eresco.

Creswell, J. W. (1998). Qualitative inquiry and research design: choosing among five traditions. The United State of America: Sage Publication, Inc.

Damaiyanti, M. (2008). Komunikasi terapeutik dalam praktik keperawatan. Bandung: Refika Aditama.

INL U.S. Departement. (2011). Fisiologi dan farmakologi untuk profesional adiksi.

INL U.S. Departement. (2011).Panduan terapi gangguan penggunaan zat-rawatan berkelanjutan.

Mappiare, A. (2004). Pengantar konseling dan psikoterapi. Jakarta: Raja Grafindo Persada.
Moleong, L. (2007). Metodologi penelitian kualitatif. Bandung: Remaja Rosdakarya.

Mulyana, D. (2013). Metode penelitian kualitatif paradigma baru ilmu komunikasi dan ilmu sosial lainnya. Bandung: Remaja Rosdakarya.

Mundakir. (2006). Komunikasi keperawatan aplikasi dalam pelayanan, Edisi 1. Yogyakarta: Graha Ilmu.

Northouse. (1998). Health communication: strategies for health proffesionals. Connecticut, Appleton \& Lange.

Saam, Z. (2013). Psikologi konseling ed. 1. Jakarta: Rajawali Pers.

Sukidin \& Basrowi. (2002). Metode penelitian kualitatif perspektif mikro. Surabaya: Insan Cendikia.

Suryani. (2006). Komunikasi terapeutik teori dan praktek. Jakarta: EGC.

Stuart, G. W. (1998). Principle and practice of psyciatric nursing ed. 6. St. Louis: Mosby Year Book.

West, R.\& Turner, L. H.(2008). Pengantar teori komunikasi analisis dan aplikasi. Jakarta: Salemba Humanika.

Yin, R. K. (2002). Studi kasus desain dan metode. Jakarta: Rajawali Pers. 